\title{
Acaricidal Activity of Extracts of Juglans regia L. on Tetranychus urticae Koch (Acari: Tetranychidae)
}

\author{
Pervin Erdogan ${ }^{1}$ and Betul Sever Yilmaz ${ }^{2}$ \\ 1. Plant Protection Central Research Institute, Gayret Mah. Fatih Sultan Mehmet Bulv., Yenimahalle-Ankara 6606172 , Turkey \\ 2. Faculty of Pharmacy, Ankara University, Emniyet Mah., Tandogan-Ankara 06100, Turkey
}

\begin{abstract}
Two-spotted spider mite (Tetranychus urticae Koch) (Acari: Tetranychidae) is a very serious pest worldwide, causing considerable damage to vegetables, flowers and fruit crops. The application of plant extracts to control insects can be an effective alternative. In this study, the efficacy of an extract from Juglans regia L. (Juglandecaea) was tested as an alternative to conventional acaricides. Using two different methods, bioassays were used to determine the effects of varying concentrations $J$. regia (1\%, 3\%, $6 \%, 12 \%$ ) of the extracts. Experiments were carried out using $3 \mathrm{~cm}$ diameter leaf disks of Phaseolus vulgaris L. In addition, the effects of the extract on mite reproduction and oviposition were investigated. As a result, in the leaf dipping method, the $12 \%$ concentration of the extract caused the highest mortality of nymph $(90 \%)$ and adult $(83.00 \%)$ stages. For the spraying method, the mortality of adults at the same concentration was $100 \%$. In bioassays at lower concentrations, the adult mites laid lower numbers of eggs in comparison to the untreated mites. The highest effect occurred at concentration of $12 \%$ and the lowest effect was at $1 \%$. The extract was no observed ovicidal effect.
\end{abstract}

Key words: Two-spotted spider mite, Juglans regia L., extract, acaricidal effect.

\section{Introduction}

The spider spotted mite Tetranychus urticae Koch (Acarina: Tetranychidae) is one of the most important pests which are responsible for yielding losses to many horticultural ornamental and agronomic crops. The mite has got about 1,200 species of plants, of which more than 150 are economically significant [1]. According to Tsagkarakkou et al. [2], T. urticae causes remarkable economic loss by reaching high density, especially the conditions of greenhouse are appropriate to grow this mite. Therefore, the rate of damage which causes this mite is high throughout the year. T. urticae is produced by feeding a characteristic yellow speckling on the $T$. uritace produce silk webbing that is easily visible with the high population of this pest [3].

In general, synthetic pesticides are usually used with the reason that they are easy to apply against the

Corresponding author: Pervin Erdogan, Ph.D., senior scientist, research field: effect on insect plant extracts. two spotted spider mite, and do not generally require identification of the species. However, the use of pesticides for a long time causes an ecological imbalance, side effects on natural enemies, and environmental pollution [4, 5]. Additionally, the spider spotted mite is difficult to control due to their resistance to many commonly used pesticides [6-8].

In recent years, because of the adverse effect of pesticide use, alternative control methods have been researched for $T$. urticae. Some of the alternative control methods including acaricidal effects of the plant essential oils, plant preparations and microbial secondary metabolites on two-spotted spider mites have been researched $[9,10]$. Recently, also with the intent of creating alternatives for chemical pesticides, the use of extracts obtained from some plants in the control against the pests has become more relevant [11].

Several plants contain some bioactive compounds which are biological actions against insects, including repellent, antifeedant, anti-ovipositional, toxic, 
chemosterilant, and growth regulatory activities [12, 13]. Therefore, botanical insecticides have long been used as attractive alternatives to synthetic chemical insecticides for pest management because botanical insecticides pose little threat to the environment or to human health [14]. The use of plant derivatives as an alternative to chemical insecticides has been studied throughout the world. It is determined that over 20,009 plant species have been reported to possess pest control properties [15].

Juglans regia L. (Juglandecae) is a cosmopolitan tree species whose walnuts and leaves are used for medicinal purpose [16-18]. Leaf extracts of J. regia have both insecticidal, bactericidal and antimicrobial properties [19-21]. Vang et al. [22] revealed that walnut leaf extract had both contact and systemic effect Tetranychus cinnabarinus (Boisd) and Tetranychus viennensis Zacher (Acari: Tetranychidae).

The purpose of the study was to determine the acaricidal activity of $J$. regia leaf extracts on $T$. urticae.

\section{Materials and Methods}

\subsection{Mite Culture}

T. urticae was reared in the laboratory at $25 \pm 1{ }^{\circ} \mathrm{C}$ and under long daylight (18 light: 6 dark) and 65\%-70\% relative humidity on potted bean. The bean plants (Phaseolus vulgaris L.) used in the experiment all were grown in greenhouse.

\subsection{Plant and Preparation of Extracts}

The plants used in their research were collected during 2013 in middle Anatolia around Ankara province. Plant material was collected leaves of $J$. regia. Leaves were cut at level and whole plant was used for extraction. Leaves were allowed to dry in laboratory conditions. Oven-dried leaves were ground to a fine powder. For extraction, $200 \mathrm{~g}$ of powdered plant materials and $400 \mathrm{~mL}$ of ethanol $(80 \%)$ were added to the dried powder for 72 hours. The above mixture placed into Soxhlet for 5-6 hrs. to obtain the useable extract as insecticide. After filtering through a Bucher funnel and Whatman No. 1 filter paper, the extracts were concentrated under low pressure using rotary evaporator $\left(50-60{ }^{\circ} \mathrm{C}\right)$. Crude extract was reconstituted to have the concentration of $20 \%(\mathrm{w} / \mathrm{v})$ using ethanol $80 \%$ ( $\mathrm{v} / \mathrm{v}$ in distillated water) and stored at $4{ }^{\circ} \mathrm{C}$ in glass vials to be used as stock plant extract. For the tests, these stock plant extract was dissolved in distilled water containing Triton X.100 at a rate of 0.1 $\mathrm{mL} / \mathrm{L}$ [23].

\subsection{Effect of the Extracts on T. urticae}

Ovicidal effect; Green bean leaf discs were placed into petri dishes on moistened filter paper and females of the same age were put on leaf discs. The eggs were counted after two days. Ten eggs were placed in every petri dish and the other eggs removed. Then the eggs were sprayed with different concentrations of extract $\left(17-20 \mu \mathrm{l} / \mathrm{cm}^{2}\right)$ using a small hand-held sprayer. The numbers of hatched larvae were recorded.

\subsubsection{Acaricidal Effect on Larvae and Adult}

Leaf-Dipping Method; from untreated bean leaves 3 $\mathrm{cm}$ in diameter disc was punched out. These discs were then dipped into the test solutions (for extract $1 \%, 3 \%, 6 \%, 12 \%$ and Neem Azal $\mathrm{T} / \mathrm{S} 500$ $\mathrm{mL} / 100$-liter water) for one minute. The control disc was dipped in $0.01 \%$ Triton X-100 solution. Then left to dry for 30 minutes. The treated leaf discs were placed into petri dishes which lined with moistened filter paper. Then 10 adults and larva of T. urticae were introduced onto the treated discs in separate petri dishes. Same procedure was used for control [24].

Spraying Method; bean leaf discs were placed into Petri dishes on moisturized filter paper. Then 10 adult T. urticae transferred onto the disc and using a hand held sprayer leaf discs were sprayed $\left(17-20 \mu \mathrm{l} / \mathrm{cm}^{2}\right)$ with different concentration $(1 \%, 3 \%, 6 \%, 12 \%)$, control (untreated) discs were sprayed with $(0.01 \%$ Triton X-100). After the spraying left to dry for 15 minutes. When adults dried the treated T. urticae was 
transferred to untreated leaf discs [24].

Effect on egg laying capacity; green bean leaf discs dipped for 3-5 seconds in prepared concentrations then dried for 30 minutes were placed in petri dishes with ten adults. After 48 hours of feeding on treated green bean leaves, mites were given untreated green bean leaves. The experiment was repeated 10 times. Daily monitoring was done for fourteen days and the total number of eggs was recorded [25].

The experiment was replicated 10 times including control. For each petri disc contained 10 adult 3 days old first larval stage was used. Data collection started after 1,3 , and 6 days by counting the number of living larvae and adults. The experiments were conducted in a climate chamber at $25 \pm 1{ }^{\circ} \mathrm{C}$ and under long daylight (18:6 light: dark). The effect was calculated according to Abbott [26]. The obtained results were submitted to a variance analysis and the mean values were compared by Duncan's test $(P=0.05)$ calculated by the program SPSS 20.6.

\section{Results and Discussions}

\subsection{Ovicidal Effect}

All of the eggs treated were hatched. It was revealed that extract of $J$. regia did not show any ovicidal effect.

\subsection{Effect of Extract on T. urticae}

For the larvae placed on leaf discs treated with different concentrations $J$. regia of extract, the mortality of larvae placed on leaf discs treated with concentrations of $1 \%, 3 \%, 6 \%$ and $12 \%$ was $70 \%$, $80 \%, 84 \%$ and $90 \%$ respectively. The highest effect occurred at a concentration of $12 \%$ while the smallest effect was at $1 \%$. According to statistical analysis, the difference between the concentrations was found to be significant in terms of mortality rate. According to this the concentrations of $6 \%$ and $12 \%$ were as the same group $(F=26.82 ; P=0.00)$. As for effect, it was determined that the concentrations of $1 \%$ and $3 \%$ were as the same group $(F=14.31, P=0.00)$ (Tables 1 and 2).

Leaf dipping method; the mortality of adult placed on leaf discs treated with concentrations of $1 \%, 3 \%$, $6 \%, 12 \%$ was $57 \%, 65 \%, 65 \%$ and $83 \%$ respectively. According to statistical analyses, it was found that the difference among concentrations was important $(F=$ 28.59; $P=0.00)$. The highest effect occurred at a concentration of $12 \%$ while the smallest effect was at $1 \%(F=28.48 ; P=0.00)($ Tables 1 and 2$)$.

Spraying method; the extract of $J$. regia, the mortality of spraying treated with concentrations of $1 \%, 3 \%, 6 \%$ and $12 \%$ was $72 \%, 88 \%, 90 \%$ and $100 \%$ respectively. The highest effect occurred at a concentration of $12 \%$ while the smallest effect was at $1 \%$ (Tables 1 and 2). In statistical analyses, it was found that the results are the same as mortality rate.

\subsection{Effect on Egg Laying Capacity}

All concentrations of $J$. regia extract had significant effects on eggs laid by the mite adults. It was determined that the difference was important between control and the highest concentration $(F=25.87 ; P=$ $0.00)$. The highest number of eggs was found at control. Laid number of eggs decreased depending on increasing concentration. The least number of eggs was found $12 \%$ concentration (Table 3 ).

Previously, researches showed that some plant extracts had acaricidal activity against $T$. urticae. For example, Erdogan et al. [27] reported that extracts of five different plants showed high mortality on $T$. urticae. Similarly, Numa et al. [28] found out that the extracts of Cnidoscolus acantifolius leaves caused the rate of high mortality (92\%) on larva and adult of $T$. urticae. In the another study, it was found that the ethanol extracts of leaves and branches of Croton sellowii Baill caused $69 \%$ mortality and $C$. jacobinensis Baillon was not toxic to T. urticae [29]. Additionally, pure azadirachtin of concentrations of $1 \%$ was acaricidal effect against $T$. urticae [30]. 
Table 1 Mortality of extract obtained Juglans regia on larvae and adult of Tetranychus urticae (Mean \pm SE).

\begin{tabular}{lllll}
\hline \multirow{2}{*}{ Treatment } & C. $(\%)$ & \multicolumn{3}{c}{ Mortality (\%) } \\
\cline { 3 - 5 } & & \multicolumn{2}{c}{ Leaf-dipping method } & Spraying method \\
\cline { 3 - 5 } & 1 & Larva & Adult & Adult \\
\cline { 3 - 5 } J. regia & 3 & $73.00 \pm 4.21 \mathrm{c}^{*}$ & $57.00 \pm 3.00 \mathrm{c}$ & $72.00 \pm 3.26 \mathrm{c}$ \\
& 6 & $86.00 \pm 2.58 \mathrm{a}$ & $75.00 \pm 2.60 \mathrm{~b}$ & $84.00 \pm 3.59 \mathrm{~b}$ \\
& 12 & $90.00 \pm 2.58 \mathrm{a}$ & $83.00 \pm 3.35 \mathrm{a}$ & $88.00 \pm 3.39 \mathrm{~b}$ \\
& Control & $10 \pm 1.25 \mathrm{~d}$ & $11 \pm 1.93 \mathrm{~d}$ & $9 \pm 0.95 \mathrm{~d}$ \\
\hline
\end{tabular}

*Means within rows followed by the same letter are not significantly different $(P=0.05$, Duncan's multiple range test). M.: Mortality C.: Concentrations.

Table 2 The effect of extracts obtained Juglans regia on larva and adult of Tetranychus urticae (Mean \pm SE).

\begin{tabular}{lllll}
\hline \multirow{2}{*}{ Treatment } & C. $(\%)$ & \multicolumn{3}{c}{ Effect (\%) } \\
\cline { 3 - 5 } & & \multicolumn{2}{c}{ Leaf-dipping method } & Spraying method \\
\hline & 1 & Larva & Adult & Adult \\
\cline { 3 - 5 } J. regia & 3 & $70.25 \pm 6.14 \mathrm{c}$ & $60.92 \pm 4.62 \mathrm{c}^{*}$ & $69.47 \pm 3.73 \mathrm{c}$ \\
& 6 & $74.03 \pm 6.03 \mathrm{~b}$ & $68.64 \pm 5.60 \mathrm{~b}$ & $86.56 \pm 3.84 \mathrm{~b}$ \\
& 12 & $85.20 \pm 4.80 \mathrm{a}$ & $79.47 \pm 3.49 \mathrm{a}$ & $100.00 \pm 0.00 \mathrm{a}$ \\
\hline
\end{tabular}

*Means within rows followed by the same letter are not significantly different $(P=0.05$, Duncan's multiple range test). M.: Mortality; C.: Concentrations.

Table 3 Number of eggs (mean \pm SE) of extracts obtained Juglans regia on Tetranychus urticae (Mean \pm SE).

\begin{tabular}{lll}
\hline Treatment & Concentrations $(\%)$ & Number of eggs \\
\hline & 1 & $139.70 \pm 6.86 \mathrm{c}$ \\
\multirow{3}{*}{ regia } & 3 & $106.20 \pm 11.71 \mathrm{c}$ \\
& 6 & $67.90 \pm 7.29 \mathrm{~b}$ \\
& 12 & $61.70 \pm 6.81 \mathrm{a}$ \\
& Control & $149.90 \pm 6.712 \mathrm{c}$ \\
\hline
\end{tabular}

*Means within rows followed by the same letter are not significantly different $(P=0.05$, Duncan's multiple range test). M.: Mortality; C.: Concentrations.

Also, it was observed that the extracts showed reduced fecundity on the female of T. urticae [31, 32]. Pure azadiractin reduced the number of eggs laid by $T$. urticae [33]. Commercial formulations named Neem Azal T/S reduced oviposition of $T$. urticae [24, 34]. In addition, it was reported that the number of eggs laid T. Urticae female caused a reduction on the plants extracts was applied $[35,36]$.

In our studies, it was determined that $J$. regia extract mortality larvae and adult of was found the highest compared to the control. Also, it was observed that the extracts showed reduced fecundity on the female of T. urticae. There were no references found on other studies done using $J$. regia extracts against $T$. urticae. But, there were a few references studies done $J$. regia extracts against different mites and insects. For example, extract of J. regia showed that the female of Tetranychus cinnabarinus mortality was $83.44 \%$ at $24 \mathrm{~h}$ after exposed in the petroleum ether extract $\left(1 \mathrm{mg} \cdot \mathrm{mL}^{-1}\right)$ from walnut green husk, which was significantly higher than that in the chloroform and methanol extracts [37]. Similarly, Zhai et al. [38] revealed that walnut leaves extract had effect an stomach poisoning action to Mythimna separata Walker (Lep.: Noctuidae) and Plutella xylostella L. (Lep.: Plutellidae). It was determined that the extract 
of obtained from walnut leaves had strong contact effect on aphid than that on Stilpnotia candidate L. (Lep.: Lymantridae) [39]. Leaf extract of the walnut showed, J. regia L., showed that they both had contact and systemic toxicity acaricidal activity on the mites Tetranychus cinnabarinus (Boisduval) and Tetranychusviennensis Zacher (Acari: Tetranychidae) [40]. J. regia leaves composed of terpenes, hydrocarbons, esters, flavonoids and phenolic compounds [41]. It was revealed that phenolic compounds such as tannins, flavanols and flavonoids were toxic to bacteria, fungi and insects [42]. Also, J. regia leaves contained juglona, which had pesticidal and herbicidal effect [43].

\section{Conclusions}

It was determined that $J$. regia extract mortality larvae and adult of was found the highest compared to the control. Also, it was observed that the extracts showed reduced fecundity on the female of T. urticae. This is the first report about acaricidal effect of $J$. regia extract on $T$. urticae. According to the results of this study, J. regia extract could be used against $T$ urticae plants grown in IPM after determining the active component of this extract, and carrying out field experiment.

\section{Acknowledgments}

The authors are grateful to Dr. Numan E. Babaroglu for statistical analysis. Plant Protection Central Research Institute Ankara-Turkey.

\section{Author Contributions}

The initial idea of the study was conceived by Pervin Erdogan collected the plant of J. regia. Pervin Erdogan assisted with the design of experimental protocol. Pervin Erdogan performed all of experiment. Betul Sever Yilmaz prepared plant extract.

\section{Conflicts of Interest}

The authors declare no conflict of interest.

\section{References}

[1] Zhang, Z. 2003. Mites of Greenhouses; Identification, Biology and Control. Wallingford, UK: CABI Publishing.

[2] Tsagkarakou, A., Navajas, M., Rousser, F., and Pasteur, N. 1999. "Genetic Differentiation in Tetranychus urticae (Acari: Tetranychidae) from Greenhouses in France.” Exp. Appl. Acarol. 23: 365-78.

[3] Jeppson, L. R., Keifer, H. H., and Baker, E. V. 1975. Mites Injurious to Economic Plants-1. Berkeley: University of California Press, 383.

[4] Stampf, N., and Naven, R. 2001. "Cross Resistance, Inheritance, and Biochemistry of Mitochondrial Electron Transport Inhibitor-Acaricide Resistance in Tetranychus urticae (Acari: Tetranychidae).” J. Econ. Entomology 94: 1577-83.

[5] Van Leeuwen, T. V., Tirry, L., and Nauen, R. 2006. "Complete Maternal Inheritance of Bfenazate Resistance in Tetranychus urticae (Acari: Tetranychidae) and Its Implications in Mode of Action Considerations." Insect Biochhemistry and Moleculer Biology 36: 869-77.

[6] Cranham, J. L. F., and Helle, W. 1985. "Pesticide Resistance in Tetranychidae." In Spider Mites Their Biology, Natural Enemies and Control, edited by Helle, W, and Sabelis, M. W. Amsterdam: Elsevier, 405-22.

[7] Shi, G. L., Zhao, L. L., Liu, S. Q., Cao, H., Clarke, S. R., and Sun, J. H. 2006. "Acaricidal Activities of Extracts of Kochia Scoparia against Tetranychus urticae, Tetranychus cinnabarinus and Tetranychus viennensis (Acari: Tetranychidae).” J. Econ. Entomology 99: 858-63.

[8] Shen, H. M. 1999. "Resistance and Cross-Resistance of Tetranychus viennensis (Acari: Tetranychidae) to 14 Insecticides and Acaricides." Syst. Appl. Acarol. 4: 9-14.

[9] Calmasur, O., Aslan, I., and Sahin, F. 2006. "Insecticidal and Acaricidal Effect of Three Lamiaceae Plant Essential Oils against Tetranychus urticae Koch.” Bemisia tabaci Genn. Ind. Crop Prod. 23: 140-6.

[10] Villanueva, R. T., and Walgenbach, J. F. 2006. "Acaricidal Properties of Spinosad against Tetranychus urticae and Pnonychus ulmi (Acari: Tetranychidae)." J. Econ. Entomology 99 (3): 843-9.

[11] Feng, R., and Isman, M. B. 1995. "Selection for Resistance to Azadirachtin in the Green Peach Aphid Mysuz persicae." Experimentia 51: 831.

[12] Singh, R. N., and Saratchandra, B. 2005. "The Development of Botanical Products with Special Reference to Seri-Ecosystem." Caspian J. Env. Sci. 3: 1-8.

[13] Sertkaya, E., Kammuran, K. K., and Soylu, S. 2010. "Acaricidal Activities of the Essential Oils from Several Medicinal Plants against the Carmine Spider Mite 
Tetranychus cinnebarinus Boisd (Acarina: Tetranchidae)." 1. Crop Prod. 31: 107-12.

[14] Isman, M. B. 2006. "Botanic Insecticides, Deterrents, and Repellents in Modern Agriculture and Increasingly World." Ann. Rev. Entomology 51: 45-66.

[15] Ahmed, S. G. M., Hylin, J. W., Mitchell, W. C., and Litsinger, J. A. 1984. "Investigating the Feasibility of Using Botanical Materials for Pests Control under Traditional Farming System: A Suggested Neem Approach." In Proceedings of 2nd International Neem Conference, Rauischholzhausen, 545-50.

[16] Ma, L. H., Qin, W. D., and Miao, J. Z. 2006. "Study on a Milk Beverage of Walnut and Hawthorn." Food Res. Dev. 27: 90-2.

[17] Xu, Z. H., Tan, J. H., Zhang, X., Wang, L., and Li, W. Y. 2006. "Study on the Extraction of Natural Food Coloring Matter from Walnut Outer Peel and Its Phsical-Chemical Properties.” J. Sichuan Normal Univ. 29: 488-90.

[18] Zhou, Y. Y., and Lv., B. 2006. "Study on the Walnut Milk." Food Sci. Technol. 2: 69-72.

[19] Zhai, M. Z., Li, X. M., Lin, Q. Y., and Xie, L. H. 2003. "Extract of Inhibiting Composition and Inhibitory Activity from Walnut Leaves." J. Northwest For. Univ. 4: 89-91.

[20] Liu, C. Q., Wang, G. R., and Liu, Y. J. 2005. "Study on Antifungal Action of Ethanol Extracts from Fructus kochiae." Chin J. Pract. Chin. Mod. Med. 18: 658.

[21] Yigit, A., and Erkilic, L. 1992. "Studies on the Chemical Control of Tetranychus cinnabarinus Boisd. (Acarina: Tetranychidae), a Pest of Strawberry in the East Mediterranean Region of Turkey." Crop Protection 11: 433-8.

[22] Wang, N., Wang, H. X., Liu, Y., and Shi, G. 2012. "Insecticidal Activity of Juglans regia Extracts against Tetranychus cinnabarinus and Their Effects on Relative Enzymes Activity in Tetranychus cinnabarinus." Information Technology and Agricultural Engineering 134: 611-20.

[23] Bussaman, P., Sa-uth, C., Rattanasena, P., and Chandrapatya. A. 2012. Effect of Crude Plant Extract on Mushroom Mite, Luciaphorus sp. (Acari: Pygmephoridae). Hind. Publishing Corporation. Psyche., doi: $10.1155 / 2012 / 150958$.

[24] Miranova, M. K., and Khorkhordin, E. G. 1996. "Effect of Neem Azal T/S on Tetranychus urticae Koch.” In Proceedings at the 5th Workshop, Wetzlar, Germany, 22-5.

[25] Schmutterer, H. 1986. "Fecundity Reducing and Sterilizing Effects of Neem Seed Kernel Extracts in the Colorado Potato Beetle, Leptinotarsa decemlineata." In Proceedings of 3rd International Neem Conference, Nairobi, 351-60.
[26] Abott, W. S. 1923. "A Method of Computing the Effectiveness of an Insecticide." J. Econ. Entomology 18: 265-7.

[27] Erdogan, P., Yildirim, A., and Sever, B. 2012. Investigations on the Effects of Five Different Plant Extracts on the Two-Spotted Mite Tetranychus Urticae Koch (Acarina: Tetranychidae). Psyche: Hindawi Publishing Corporation.

[28] Numa, S. L., Rodrigues, D., and Barrera, E. C. 2015. Susceptibility of Tetranychus urticae Koch to an Ethanol Extract of Cnidoscolus Aconitifolius Leaves under Laboratory Conditions. Springer Plus, 43: 38 doi: 10.1186/s40064-015-1127.

[29] Wendel, J. T. P., Jose, C. S. D., Claudio, A. G., and Adelmo, C. H. R. 2007. "Compositon and Acaricidal Activity of the Resin's Essential Oil of Protium bahianum Daly against Two Spotted Spider Mite (Tetranychus urticae)." J. Essentiol Oil Research 19: 379-83.

[30] Sundaram, K. M. S., and Sloane, L. 1995. "Effects of Pure and Formulated Azadirachtin, a Neem-Based Biopesticide, on the Phytophagous Spider Mite, Tetranychus urticae Koch.” J. Envir. Sci. Health. 30: 801-14.

[31] El-Moneim, M. A., Fatma, S. A., and Turky, A. F. 2012. "Control of Tetranychus urticae Koch by Extracts of Three Essential Oils of Chamomile, Marjoram and Eucalyptus.” Asian Pasisfic j. Trop. Biomed. 2: 24-30.

[32] Martinez-Villar, E., Saenz, C. F., Moreno, G. F., Marco, V., and Perez, M. I. 2005. "Effects of Azadirachtin on the Two Spotted Spider Mite, Tetranychus urticae Koch (Acari: Tetranychidae).” Exp. Appl. Acarol. 35: 215-22.

[33] Dimetry, N. Z., Amer, S. A., and Reda, S. A. A. 1993. "Biological Activity of Two Neem Seed Kernel Extracts against the Two-Spotted Spider Mite Tetranychus urticae Koch.” J. Apply. Entomol. 116: 308-12.

[34] Sivira, A., Sanabria, M. E., Valera, I. N., and Vásquez, C. 2011. "Toxicity of Ethanolic Extracts from Lippia origanoides and Gliricidia sepium to Tetranychus cinnabarinus (Boisduval) (Acari: Tetranychidae)." Neotrop Entomology 40: 375-9.

[35] Asharaja, A., and Sahayaraj, K. 2013. "Screening of Insecticidal Activity of Brown Macro Algal Extracts against Dysdercus cingulatus (Fab.) (Hemiptera: Pyrrhocoridae)." J. Biopest. 6: 193-203.

[36] Wang, Y. N., Wang, H. X., Liu, Y., and Shi, G. 2012. "Insecticidal Activity of Juglans Regia Extracts against Tetranychus cinnabarinus and Their Effects on Relative Enzym Activity in Tetranychus cinnabarinus." Information Technology and Agricultural Engineering 134: 611-20.

[37] Zhai, M. Z., Zhang, F. Y., Liu, C. B., and Xin, F. M. 2005. "Study on the Antifeeding Bioactivity of Extracts 
from Walnut Leaves against Mythimna separatea and Plutella xylostella." J. Nortwest For. Univ. 2: 138-40.

[38] Zhai, M. Z., Yang, X. P., and Liu, L. 2001. "The Contact Effect of Extracts from Walnut Leaves on Aphid." $J$. Nortwest For Univ. 4: 55-6.

[39] Wang, Y. N., Shi, G. L., Zhao, L. L., Liu, S. Q., Yu, T. Q., Clarke, S. R., and Sun, J. H. 2007. "Acaricidal Activity of Juglans regia Leaf Extracts on Tetranychus viennensis and Tetranychus cinnabarinus (Acari: Tetranychidae)." J. Econ. Entomol. 100: 1298-303.
[40] Buttery, R. G., Flath, R. A., Mon, T. R., and Ling, L. C. 1956. "Identification of Germacrene D in Walnut Ang Fig Leaf Volatiles.” J. J. Agric. Food. Chem. 34: 820-2.

[41] Quadan, F. A. J., Thevaini, D. A., Ali, R., A., Elkhawad, A., and Matalka, K. Z. 2005. "The Antimicrobial Activities of Psidium guajava and Juglans regia Leaf Extracts to Acne-Developing Organisms." A. J. Chin Med. 33: 197-204.

[42] Duke, J. A., and Ayensu, E. S. 1985. Medicinal Plants of China. Algonac: Reference Publ. Inc., MI. 